\section{IAC 1849 Polaco: carioca common bean cultivar with an early maturity and tolerance to seed darkening}

\author{
Alisson Fernando Chiorato ${ }^{1}$, Sérgio Augusto Morais Carbonell ${ }^{1}$, \\ Luiza Maria Capanema Bezerra ${ }^{1}$, José Antônio de Fátima \\ Esteves ${ }^{1}$, João Guilherme Ribeiro Gonçalves ${ }^{1}$, Daiana Alves da \\ Silva ${ }^{1 *}$, Sara Regina Silvestrin Rovaris ${ }^{1}$, Acácia Mecejana Diniz \\ Souza Spitti ${ }^{1}$, Luciana Lasry Benchimol-Reis ${ }^{2}$, Cássia Regina \\ Limonta Carvalho ${ }^{2}$, Vera Lúcia Nishijima Paes de Barros ${ }^{3}$, \\ Rogério Soares de Freitas ${ }^{4}$, Marcelo Ticelli ${ }^{5}$ and Paulo Boller \\ Gallo ${ }^{6}$
}

Abstract: IAC 1849 Polaco is a common bean cultivar with a carioca (beige/ cream-colored with brown stripes) seed coat, 75-day mean maturity, semiupright plant architecture, tolerance to seed darkening, mean 1000-seed weight of 240 grams, resistance to the main diseases in common bean, and mean seed yield of $2464 \mathrm{~kg} \mathrm{ha}^{-1}$ obtained in 18 experiments.

Keywords: Phaseolus vulgaris L., plant breeding, tolerance to seed darkening, early maturity.

\section{INTRODUCTION}

Common bean (Phaseolus vulgaris) is an important source of protein in the human diet and, in some countries, one of the main sources. These countries seek to supply consumption demands through domestic production; the main producer countries are also large consumer countries. The main types of common bean (dry edible bean) consumed in Brazil have carioca (beige/cream-colored with brown stripes) or black seed coats due to the preference of the Brazilian population for a product with a pleasing appearance of the bean grain, allied with pleasing taste, high nutritional quality, and sustainability of the food produced.

Common bean breeding, especially for the carioca commercial type that represents $79 \%$ of the dry bean market in Brazil (Ribeiro et al. 2019), contributes in a preponderant manner to the high technological level of the crop, has resulted in high seed yields, more than $4500 \mathrm{~kg}$ per ha (Wutke et al. 2014), high seed quality, short cooking time, and delayed seed darkening, which adds value to the final product. Thus, obtaining cultivars that combine the attributes of high seed yield and quality in the field and after harvest are desirable in common bean breeding programs.

Early maturity and delayed seed darkening are increasingly desired traits in bean production and in the consumer market, and these qualities are notably
Crop Breeding and Applied Biotechnology 20(3): e30232036, 2020 Brazilian Society of Plant Breeding. Printed in Brazil http://dx.doi.org/10.1590/198470332020v20n3c40

\section{*Corresponding author: E-mail: daiagrouel2002@hotmail.com (D) ORCID: 0000-0002-4211-3308}

Received: 20 December 2019 Accepted: 06 May 2020 Published: 20 July 2020

${ }^{1}$ Instituto Agronômico, Centro de Análises e Pesquisa Tecnológica do Agronegócio dos Grãos e Fibras, 13.020-902, Campinas, SP, Brazil

${ }^{2}$ Instituto Agronômico, Centro de Pesquisa e Desenvolvimento de Recursos Genéticos Vegetais, 13.020-902, Campinas, SP, Brazil

${ }^{3}$ Agência Paulista de Tecnologia dos Negócios, Pólo Regional de Desenvolvimento Tecnológico do Agronegócio, 18.300-970, Capão Bonito, SP, Brazil

${ }^{4}$ Instituto Agronômico, Centro APTA de Seringueira e Sistemas Agroflorestais, 15.500000 , Votuporanga, SP, Brazil

${ }^{5}$ Agência Paulista de Tecnologia dos Negócios Sudoeste Paulista, Pólo Regional de Desenvolvimento Tecnológico do Agronegócio, 18.300-970, Tatuí, SP, Brazil

${ }^{6}$ Agência Paulista de Tecnologia dos Negócios Nordeste Paulista, Pólo Regional de Desenvolvimento Tecnológico do Agronegócio, 13.730-980, Mococa, SP, Brazil 


\section{AF Chiorato et al.}

present in the cultivar IAC 1849. Delayed grain darkening is related to market preferences for carioca beans with a lighter bean grain color, recognizing consumers' association of this aspect with beans that are easy to cook, even though this has not been proven scientifically (Ribeiro et al. 2019).

The early maturity of the IAC 1849 Polaco is related to production and yield aspects of the crop, reducing costs on plant management and reducing use of agricultural chemicals through lower exposure to biotic stresses, due to the shorter crop maturity. In a similar way, for abiotic factors, early maturity bean cultivars require less irrigation and energy up to the end of their 75-day cycle compared to a cultivar with a normal 90-day cycle (Buratto et al. 2007).

In 1998, the Coordenadoria de Assistência Técnica Integral (Agency for Integral Technical Assistance), SP - Cati registered the cultivar Carioca Precoce (MAPA/RNC 00456) in the Registro Nacional de Cultivares (Brazilian National Cultivar Registry) of the Ministério da Agricultura, Pecuária e Abastecimento (Brazilian Ministry of Agriculture) - MAPA/ RNC. This cultivar was traditionally grown by farmers in the state of São Paulo but had serious problems of susceptibility to common bacterial blight and low yield. Introduction of the early maturity trait in carioca cultivars through breeding programs resulted in registration of the cultivar IAC Imperador in 2012 (MAPA/RNC 29886) and later, in 2013, of the cultivars IPR Curió (MAPA/RNC 30616), IPR Andorinha (MAPA/RNC 30617), and TAA Gol (MAPA/RNC 31004), and, in 2017, of BRS FC104 (MAPA/RNC 36426). A condition desired by breeding programs is that reduction in the bean crop maturity not reduce bean yield or other agronomical traits (CultivarWeb 2019, http://sistemas.agricultura.gov.br/snpc/ cultivarweb/cultivares_registradas.php).

The cultivar IAC 1849 Polaco was developed to meet the demands of the bean production chain and offer a product with early maturity and high quality, stable grain yield, resistance to the main diseases in common bean, and tolerance to seed darkening. IAC 1849 Polaco was registered in 2019 under MAPA/RNC number 41704 in the National Cultivar Registry of the Brazilian Ministry of Agriculture.

\section{GENETIC ORIGIN AND DEVELOPMENT}

The cultivar IAC 1849 Polaco was developed by the common bean breeding program of IAC. In 2012, a cross was made between the cultivar IAC Imperador (early maturity and carioca seed coat) (Chiorato et al. 2012) and a landrace genotype called Branquinho, not registered in MAPA and used by farmers in the state of Mato Grosso for exhibiting reduced darkening of the seed coat over long periods of storage. From the crosses made, $12 \mathrm{~F}_{1}$ seeds were selected and sown in 2013 to obtain the $F_{2}$ seeds. The seedlings of the $F_{2}$ seeds were inoculated in the laboratory, under controlled temperature and moisture conditions, with a mixture of physiological races 65,81 , and 321 of the anthracnose pathogens and 20 resistant plants were selected.

The $20 \mathrm{~F}_{2: 3}$ plants selected were transplanted in pots and harvested individually, i.e., these $\mathrm{F}_{3}$ seeds harvested were immediately sown in the 2014 dry crop season (in January) in the IAC experimental field for evaluation of resistance to the Fusarium oxysporum fungus, through the natural contamination already existing in the area. In this experiment, selections were made within the progenies, and $\mathrm{F}_{4}$ seeds were harvested from 20 plants. In the 2014 winter crop season, the 20 progenies of the $\mathrm{F}_{4}$ plants were selected in an area with natural contamination of Fusarium oxysporum.

In this generation, one plant from each progeny was selected and $\mathrm{F}_{5}$ seed harvested. In October 2014, the rainy crop season, $\mathrm{F}_{5}$ seeds were part of an experiment containing 495 lines from other IAC crosses of the Common Bean Breeding Program of IAC (PMGF-IAC). This experiment was also sown in the municipality of Campinas in an area contaminated with Fusarium oxysporum. An advanced early maturing line Gen 78-1A-59 was selected. The name of the line refers to:

Gen: Abbreviation used to designate advanced lines in the common bean breeding program of IAC.

78: Number of the cross combination performed between the genotypes IAC Imperador x Branquinho.

1A: Number of the pot in which the plant selected in the anthracnose resistance evaluations was obtained. The number 1 means the number of the pot, and the letter A means that it was resistant to anthracnose.

59: number of the line from the field where the line was selected in the $\mathrm{F}_{5}$ generation of the experiment, resistant to Fusarium oxysporum wilt. 
In 2016 dry crop season, the line Gen 78-1A-59 was part of the Value for Cultivation and Use (VCU) trials in the state of São Paulo for the 2016/2017 biennial period, together with 10 other advanced lines developed by the IAC breeding program.

\section{YIELD CAPACITY}

The VCU experiments were conducted in 18 environments over the years 2016 and 2017 in the three different crop seasons in municipalities of the state of São Paulo (Table 1). The cultivars used as controls for the carioca group were IAC Sintonia, IAC Milênio, and BRS Pérola. As observed in Table 1, the line Gen 78-1A-59 exhibited a mean overall yield of $2464 \mathrm{~kg} \mathrm{ha}^{-1}$, statistically equal to the check cultivars BRS Perola, IAC Milenio and IAC Sintonia in the VCU trials. Due to the good yield performance compared to the other standard control cultivars, together with its early cycle of around 75 days (data not shown), as well as exhibiting high tolerance to seed coat darkening a trait highly desired by the production sector, the line Gen 78-1A-59 will be recommended for growing by the Instituto Agronômico - IAC under the name of IAC 1849 Polaco.

In the numbering 1849 used to designate the name of the cultivar, 18 refers to the year 2018, the year the genotype was reported for recommendation to the productive sector, and 49 corresponds to the forty-ninth common bean cultivar developed by the common bean breeding program of IAC.

\section{OTHER CHARACTERISTICS}

The plants of the IAC 1849 Polaco cultivar have a semi-upright plant architecture and type I determinate growth habit. The mean cycle is 75 days from emergence to physiological maturity, in accordance with environmental growing conditions, and it is considered to have an early maturity. The cultivar IAC 1849 Polaco has carioca type seeds grains with a cream-colored seed coat with light brown stripes. The mean 1000-seed weight is 240 grams, and it has delayed seed darkening.

Table 1. Grain yield $\left(\mathrm{kg} \mathrm{ha}^{-1}\right)$ of common bean cultivars in 2016/2017 VCU experiments conducted in 18 environments in three different crop seasons

\begin{tabular}{|c|c|c|c|c|c|c|c|c|}
\hline \multirow{2}{*}{ Location } & \multirow{2}{*}{ Crop season } & \multirow{2}{*}{ Year } & \multirow{2}{*}{$\begin{array}{c}\text { Gen 78-1A-59 } \\
\left(\mathrm{kg} \mathrm{ha}^{-1}\right)\end{array}$} & \multicolumn{3}{|c|}{ Controls $\left(\mathrm{kg} \mathrm{ha}^{-1}\right)$} & \multirow{2}{*}{$\begin{array}{l}\text { Mean yield of } \\
\text { controls }\end{array}$} & \multirow{2}{*}{$\begin{array}{l}\text { CV } \\
(\%)\end{array}$} \\
\hline & & & & BRS Pérola & IAC Milênio & IAC Sintonia & & \\
\hline Mococa & Rainy & 2016 & 2167 & 2246 & 1846 & 2338 & 2143 & 12.37 \\
\hline Campinas & Rainy & 2016 & 1850 & 1254 & 929 & 1933 & 1372 & 18.29 \\
\hline Capão Bonito & Rainy & 2016 & 4375 & 3746 & 3779 & 3992 & 3839 & 14.11 \\
\hline Tatuí & Dry & 2016 & 1980 & 2402 & 974 & 2273 & 1883 & 15.05 \\
\hline Campinas & Dry & 2016 & 3467 & 3925 & 4017 & 3708 & 3883 & 14.39 \\
\hline Capão Bonito & Dry & 2016 & 2250 & 1725 & 1654 & 2529 & 1969 & 24.61 \\
\hline Ribeirão Preto & Winter & 2016 & 1775 & 1888 & 2275 & 1988 & 2050 & 24.90 \\
\hline Campinas & Winter & 2016 & 2988 & 2779 & 2933 & 3517 & 3076 & 15.28 \\
\hline Votuporanga & Winter & 2016 & 2760 & 2808 & 3658 & 2949 & 3138 & 19.80 \\
\hline Mococa & Rainy & 2017 & 2175 & 2296 & 2896 & 2471 & 2554 & 12.85 \\
\hline Campinas & Rainy & 2017 & 2320 & 2605 & 2330 & 2650 & 2528 & 16.21 \\
\hline Capão Bonito & Rainy & 2017 & 2150 & 2250 & 1860 & 2050 & 2053 & 18.12 \\
\hline Tatuí & Dry & 2017 & 2220 & 1890 & 1910 & 2345 & 2048 & 21.23 \\
\hline Campinas & Dry & 2017 & 2455 & 2505 & 2630 & 2255 & 2463 & 18.36 \\
\hline Capão Bonito & Dry & 2017 & 2650 & 2160 & 2225 & 2710 & 2365 & 11.78 \\
\hline Votuporanga & Winter & 2017 & 3133 & 2500 & 2458 & 2325 & 2428 & 17.42 \\
\hline Ribeirão Preto & Winter & 2017 & 1450 & 1780 & 1560 & 1110 & 1483 & 23.25 \\
\hline Campinas & Winter & 2017 & 2180 & 1960 & 2100 & 2235 & 2098 & 22.87 \\
\hline \multicolumn{3}{|c|}{ Mean of Rainy (1st) $\left(\mathrm{kg} \mathrm{ha}^{-1}\right)$} & 2506 & 2400 & 2273 & 2572 & 2415 & 23.85 \\
\hline \multicolumn{3}{|c|}{ Mean of Dry (2nd) $\left(\mathrm{kg} \mathrm{ha}^{-1}\right)$} & 2504 & 2435 & 2235 & 2637 & 2436 & 17.35 \\
\hline \multicolumn{3}{|c|}{ Mean of Fall-Wint. (3rd) $\left(\mathrm{kg} \mathrm{ha}^{-1}\right)$} & 2381 & 2286 & 2497 & 2354 & 2379 & 19.95 \\
\hline \multicolumn{3}{|c|}{ Overall Mean (kg ha-1) } & 2464 & 2373 & 2335 & 2521 & 2410 & 18.29 \\
\hline
\end{tabular}

* Dunnett test $(p<0.05)$. 
Table 2. Technological and nutritional quality: mean values of cooking time by the Mattson Cooker and percentage of protein by the microKjeldahl in common bean seeds, grown in the $2016 / 2017$ biennial

\begin{tabular}{|c|c|c|c|c|c|c|}
\hline \multirow[b]{2}{*}{ Crop Season } & \multicolumn{2}{|c|}{ Gen 78-1A-59 } & \multicolumn{2}{|c|}{ IAC Milênio } & \multicolumn{2}{|c|}{ BRS Pérola } \\
\hline & $\begin{array}{l}\text { Cooking Time } \\
(\min )\end{array}$ & $\begin{array}{c}\text { Protein Content } \\
(\%)\end{array}$ & $\begin{array}{l}\text { Cooking Time } \\
(\min )\end{array}$ & $\begin{array}{c}\text { Protein Content } \\
(\%)\end{array}$ & $\begin{array}{c}\text { Cooking Time } \\
(\mathrm{min})\end{array}$ & $\begin{array}{c}\text { Protein Content } \\
(\%)\end{array}$ \\
\hline Winter 2016 & 33.26 & 18 & 38.38 & 19 & 37.14 & 19 \\
\hline Rainy 2016 & 31.58 & 19 & 38.38 & 20 & 33.36 & 18 \\
\hline Rainy 2017 & 33.89 & 18 & 36.95 & 19 & 35.62 & 19 \\
\hline Mean & 30.6 & 18.6 & 35.1 & 19.3 & 32.7 & 19 \\
\hline
\end{tabular}

Under natural growing conditions, the IAC 1849 Polaco cultivar is resistant to anthracnose (Colletotrichum lindemuthianum) and moderately resistant to angular leaf spot (Phaeoisariopsis griseola), fusarium wilt (Fusarium oxysporum), bacterial blight (Xanthomonas campestris), and bacterial wilt (Curtobacterium flaccumfaciens pv. flaccumfaciens).

As shown in Table 2, for combined analysis of the data, the mean cooking time (31.4 min) by the Mattson Cooker (Proctor and Watts 1987) and protein content in the grain (18\%) by microKjeldahl method (AOAC 1980, Bataglia et al. 1983) of the IAC 1849 Polaco cultivar were similar to those of the controls. These results qualify the cultivar to achieve good acceptability in the consumer market.

\section{TECHNICAL RECOMMENDATION AND SEED PRODUCTION}

The cultivar IAC 1849 Polaco is recommended for growing in the rainy growing season, dry growing season, and winter growing season in the state of São Paulo, and in the rainy growing season and dry growing season in the states of Paraná, Santa Catarina, Rio Grande do Sul, and Mato Grosso do Sul. A between-row spacing of $50 \mathrm{~cm}$ and 12 plants per linear meter is recommended, resulting in 240.000 plants per hectare.

IAC 1849 Polaco was registered in the MAPA/RNC in 2019 under number 41704 and seeds are available from the Núcleo de Produção de Sementes (Seed Production Center) of the Instituto Agronômico - IAC.

\section{REFERENCES}

AOAC (1980) Official methods of analysis. $13^{\text {th }}$ edn, The Association of Official Analytical Chemists/US Government Printing Office, Washington D.C..

Bataglia OC, Furlani AMC, Teixeira JPF, Furlani PR and Gallo JR (1983) Métodos de análise química de plantas. Instituto Agronômico, Campinas, 48p. (Boletim Técnico, 78).

Buratto JS, Moda-Cirino V, Fonseca Júnior NS, Prete CEC and Faria RT (2007) Adaptabilidade e estabilidade produtiva em genótipos precoces de feijão no estado do Paraná. Semina: Ciências Agrárias 28: $373-380$.

Chiorato AF, Carbonell SAM, Carvalho CRL, Barros VLNP, Borges LB, Ticelli M, Gallo PB, Finoto EL and Santos NCB (2012) IAC Imperador: early maturity "carioca" bean cultivar. Crop Breeding and Applied Biotechnology 12: 4.

Proctor JR and Watts BM (1987) Development of a modified Mattson bean cooker procedure based on sensory panel cookability evaluation. Canadian Institute of Food Science and Technology Journal 20: 9-14.

Ribeiro ND, Casagrande CR, Mezzomo HC, Kläsener GR and Steckling SM (2019) Consumer preference and the technological, cooking and nutritional quality of carioca beans. Semina: Ciências Agrárias 40: 651-664.

Wutke EB, Carbonell SAM, Chiorato AF, Esteves JAF, Ito MF, Stein CP, Brunini $O$ and Gallo PB (2014) Feijão (Phaseolus vulgaris L.). In Aguiar ATE, Gonçalves C, Paterniani MEAGZ, Tucci MLSA and Castro CEF (eds) Instruções agrícolas para as principais culturas econômicas. Instituto Agronômico, Campinas, p. 170-172. 